\title{
Subthalamic deep brain stimulation for the treatment of Parkinson disease
}

\section{Głęboka stymulacja jądra niskowzgórzowego w leczeniu choroby Parkinsona}

\author{
Tomasz Mandat ${ }^{1,2}$, Tomasz Tykocki ${ }^{2}$, Henryk Koziara ${ }^{1,2}$, Dariusz Koziorowski ${ }^{3}$, Bogdan Brodacki', Rafał Rola, ${ }^{5,6}$, Wieslaw Bonickil, \\ Pawel Nauman ${ }^{1,2}$
}

${ }^{1}$ Center of Oncology Maria Sklodowska-Curie Memorial Institute, Warsaw, Poland

2Department of Neurosurgery, Institute of Psychiatry and Neurology, Warsaw, Poland

${ }^{3}$ Department of Neurology, Health Sciences Division, Medical University of Warsaw, Warsaw, Poland

${ }^{4}$ Department of Neurology, Military Medical Institute, Warsaw, Poland

5 [st Department of Neurology, Institute of Psychiatry and Neurology, Warsaw, Poland

${ }^{6}$ Department of Physiology and Pathophysiology, Medical University of Warsaw, Warsaw, Poland

Neurologia i Neurochirurgia Polska 2011; 45, 1: 32-36

\begin{abstract}
Background and purpose: The role of subthalamic nucleus deep brain stimulation (STN DBS) in the treatment of Parkinson disease (PD) is well established. The authors present a group of patients diagnosed with PD who were treated with STN DBS. Material and methods: Between 2008 and 2009, 32 female and 34 male patients with PD were treated with STN DBS. Mean age at implantation was $57 \pm 12$ years. PD lasted from 6 to 21 years (mean 10 years). Patients were qualified for the surgery according to the CAPSIT-PD criteria. The STN was identified with direct and indirect methods. Macrostimulation and microrecording for STN identification were used in all cases. A unilateral STN DBS system was implanted in two cases and bilateral implantation was performed among rest of the group. Outcome was assessed six months after implantation. Results: The mean reduction of UPDRS III score among 51 patients who underwent follow-up was $45 \%$ (5-89\%). Reduction of levodopa consumption varied from 15 to $100 \%$. Infection forced the authors to remove the DBS system in one case four months after implantation. Skin erosion above the internal pulse generator was noted in four cases.

Conclusions: Cardinal symptoms of Parkinson's disease can be safely and effectively treated with STN DBS in selected group of patients.
\end{abstract}

\section{Streszczenie}

Wstęp i cel pracy: Rola głębokiej stymulacji jądra niskowzgórzowego (subthalamic nucleus deep brain stimulation - STN DBS) w leczeniu choroby Parkinsona (ChP) jest uznana. Autorzy przedstawiają grupę chorych na $\mathrm{ChP}$, leczonych za pomocą STN DBS.

Materiał i metody: W latach 2008-2009 metodą STN DBS leczono 32 kobiety i 34 mężzzyzn chorych na ChP. Średni wiek operowanych chorych wynosił $57 \pm 12$ lat, czas trwania choroby 6-21 lat ('srednio 10 lat). Pacjenci byli kwalifikowani do operacji na podstawie kryteriów zawartych w CAPSIT-PD. Jądro niskowzgórzowe identyfikowano metodą bezpośrednią i pośrednią. Zabieg przeprowadzono w znieczuleniu miejscowym, wykorzystując mikrorejestrację oraz makrostymulację. U 2 pacjentów implantowano elektrody jednostronnie, u pozostałych etapowo, obustronnie. Skuteczność leczenia oceniano po 6 miesiącach od implantacji.

Wyniki: W grupie 51 chorych, u których przeprowadzono ocenę skuteczności leczenia, stwierdzono zmniejszenie punktacji w III części UPDRS średnio o 45\% (5-89\%). Zmniejszenie dawki lewodopy wahało się pomiędzy 15 a 100\%. W badanej grupie stwierdzano powikłanie infekcyjne $\mathrm{u}$ jednego pacjenta oraz erozję skóry nad stymulatorem u 4 chorych.

Correspondence address: dr med. Tomasz Mandat, Centrum Onkologii - Instytut, Klinika Nowotworów Układu Nerwowego, ul. Roentgena 5 , 02-781 Warszawa, e-mail: tomaszmandat@yahoo.com

Received: 27.04.2010; accepted: 12.10.2010 
Key words: Parkinson disease, deep brain stimulation, subthalamic nucleus.
Wnioski: Stymulacja jądra niskowzgórzowego jest metodą bezpieczną i skuteczną w leczeniu objawów kardynalnych dla wybranej grupy chorych na ChP.

Słowa kluczowe: choroba Parkinsona, głęboka stymulacja mózgu, jądro niskowzgórzowe.

varied between $21 \%$ and $72 \%$ (mean 44\%). The clinical state of patients in the group was evaluated as stage II-IV on the Hoehn-Yahr scale. After neurological, psychological and neurosurgical qualification, patients were admitted to the department of neurosurgery [14] 24 hours before surgery and antiparkinsonian drugs were withdrawn. Procedures were performed under local and general anaesthesia. After the stereotactic frame fixation and CT scanning, the $\mathrm{CT}$ and MRI scans were merged [15]. The target point was calculated using indirect (mid. AC-PC: 11, -2, -4) and direct methods that modified the position depending on the MRI image. Microrecording and macrostimulation were performed in all cases with two to five electrodes [16-18]. After the target point was identified, the permanent electrode was implanted and its location was verified with fluoroscopy. In a bilateral procedure, these steps were repeated for the opposite side. After removing the stereotactic frame, under general anaesthesia the connecting cable was conducted, assembled with the internal pulse generator, and the system was internalized. Programming the internal pulse generator took place six weeks after surgery $[19,20]$. In two cases electrodes were implanted unilaterally, and in the rest of the group the procedure was staged, bilateral. Follow-up was conducted six months after surgery.

\section{Results}

The follow-up was performed after 6 months among 51 patients $(77 \%)$. Mean reduction of UPDRS part III score was $45 \%$ (5-89\%). The best results (66\% improvement) were achieved in bradykinesia and rigidity (items 22-27 and 31 in UPDRS). Poorer results (32\% improvement) were achieved in speech, facial expression and tremor (items 18-21 in UPDRS). The poorest results $(8 \%)$ were achieved in axial symptoms (28, 29 and 30 from UPDRS). Reduction of levodopa doses ranged from 15 to $100 \%$ (average $48 \%$ ). In two cases, the levodopa daily dose was reduced to zero in 6-month follow-up. An infection was observed in 1 case (1/131 implantations, $0.7 \%)$, which forced the authors 
to remove the system. Three months after completion of targeted antibiotic therapy the system was reimplanted. In 4 cases (4/131 implantations, 3\%) skin erosion was observed over the internal pulse generator, cerebral electrode or connector. In these patients, reconstructive surgery was performed without removal of the system. In 3 cases (3/131 implantations, 2.3\%) clinically asymptomatic intracerebral haemorrhage located on the path of the electrode was found at control CT. In a further CT (1 month later) the haematoma had disappeared. A clinically asymptomatic intraventricular haemorrhage was reported in 1 case ( $1 / 131$ implantations, $0.7 \%)$ on control CT, which disappeared within 1 week of observation (control CT). Motor, sensory or autonomic side effects of stimulation of the STN surrounding structures were eliminated during programming. Symptoms associated with the limbic STN stimulation appeared in 3 patients after the internal pulse generator was switched on in 1- to 4-week follow-up. The patient's relatives reported hypomanic or manic behaviour in 3 patients $(3 / 66,4.5 \%)$. Patients who presented manic or hypomanic symptoms denied any side effects.

\section{Discussion}

The history of functional neurosurgery, which aims at neuromodulation of the nervous system, begins in the nineteenth century. In the first half of the last century, spontaneous improvement was noticed among patients with extrapyramidal symptoms, which appeared after a stroke of specific brain regions. Lack of effective therapeutic methods contributed to experimental and often risky neurosurgical procedures. One of those methods was a procedure based on lesioning of certain brain structures using high or low temperatures, chemicals or radiation. The introduction of the modern stereotactic frame by Spiegel and Wycis in the mid-twentieth century was a breakthrough for functional neurosurgery. Procedures have become accurate and the high prevalence of surgery enabled larger groups of patients to be observed. Objective assessment of the effectiveness of ablative procedures was achieved as well. Another breakthrough in PD treatment was the introduction of an animal model of PD that helped to identify the neuronal loops. Alternation of those loops resulted in certain symptoms and enabled the identification of anatomical targets for neurosurgical treatment [3,4,8,21-24]. The idea of neuromodulation is to suppress the hyperactive elements or interrupt pathways between hyperac- tive and other elements of the loops. It is accepted that hyperactivity of the STN plays a key role in most PD symptoms, but attempts to lesion the STN (subthalamotomy) were associated with high risk of persistent dyskinesia, ballism or psychiatric symptoms. When performing ablative procedures for PD, most authors use test, intraoperative stimulation, which is aimed at determining the effectiveness and safety of the treatment. The main drawback of ablative surgery, even with intraoperative macrostimulation, is the irreversibility of its effects. The next natural step was the introduction of the internal pulse generator for constant and persistent brain stimulation. Due to technical difficulties, the use of neurostimulators until the early 1990s was very limited. The introduction of DBS with its reversible mechanism of action enabled safe bilateral suppression of the hyperactive STN. STN DBS has provided an improvement of cardinal symptoms of PD that included bradykinesia, rigidity and tremor [4,6,7,10,24-26].

The mechanism of action of DBS is not fully understood. Currently, the following main mechanisms of action of STN DBS are recognized: depolarization blockage (blockage of sodium channels), synaptic depolarization blockage, antidromic stimulation of the target nucleus with the topical release of GABA, masking of inhibitory coded information and activation of local inhibitory mechanisms in the target structure [3,8-10,27].

Complications associated with the introduction of DBS surgery are conditioned by the surgery and stimulation of the surrounding structures. Complications related to DBS implantation are primarily intracerebral haemorrhages, intracranial haematomas, infection, skin erosion over the implant, cerebrospinal fluid leakage or displacement of the implant. The incidence of surgical complications in DBS is estimated at 2-3\%. Neurological morbidity is estimated at $1 \%$ and mortality at $0.4 \%$. Adverse effects related to stimulation of the surrounding structures appear after initiation of the stimulation; they are usually eliminated during the programming session. Dyskinesias that appear after turning on the internal pulse generator are usually the result of a synergistic effect of medication and STN DBS, which should be interpreted as a favourable prognostic factor. Reduction of medication doses or reduction of the stimulation amplitude can eliminate dyskinesias. Hypomanic or manic behaviour, the symptoms of stimulation of the limbic part of the STN, are often denied by patients. During each programming session of the DBS, a careful medical history should be taken, from both the patients and their relatives [1,2,28-34]. 
To sum up, the introduction of the modern internal pulse generator, the consensus on qualifying for $\mathrm{PD}$ treatment, and standardization of the implantation process itself, are the main causes of the rapid development of functional neurosurgery in the last two decades, especially in the treatment of PD with STN DBS.

\section{Conclusions}

STN DBS is a safe and effective method of treatment of cardinal symptoms in a selected group of PD patients.

\section{Acknowledgement}

'Subthalamic deep brain stimulation for the treatment of Parkinson disease' has been orally presented at the Scientific Conference of the Stereotactic and Functional Neurosurgery Section of the Polish Neurosurgical Association at Ustron, Poland on March 4-5, 2010.

\section{Disclosure}

Authors report no conflict of interest.

\section{References}

1. Jarraya B., Bonnet A.M., Duyckaerts C., et al. Parkinson's disease, subthalamic stimulation, and selection of candidates: a pathological study. Mov Dis 2003; 18: 1517-1520.

2. Limousin P., Speelman J.D., Gielen F., et al. Multicentre European study of thalamic stimulation in parkinsonian and essential tremor. J Neurol Neurosurg Psychiatry 1999; 66: 289-296.

3. Starr P.A., Vitek J.L., Bakay R. Deep brain stimulation for movement disorders. Neurosurg Clin North Am 1998; 9: 381-400.

4. Lang A. Surgery for Parkinson disease: a critical evaluation of state of the art. Arch Neurol 2000; 57: 1118-1125.

5. Volkmann J. Deep brain stimulation for treatment of Parkinson's disease. J Clin Neurophysiol 2004; 21: 6-17.

6. Benabid A.L., Krack P., Benazzouz A., et al. Deep brain stimulation of the subthalamic nucleus for Parkinson's disease: methodologic aspects and clinical criteria. Neurology 2000; 55 (12 Suppl 6): S40-S44.

7. Deep-Brain Stimulation for Parkinson's Disease Study Group. The deep-brain stimulation for Parkinson's disease study group. Deep brain stimulation of the subthalamic nucleus or the pars interna of the globus pallidus in Parkinson's disease. $N$ Engl J Med 2001; 345: 956-964.

8. Gildenberg P.L. Neurosurgical treatment of movement disorders: history and update. Semin Neurosurg 2001; 12: 139-148.

9. Betchen S., Kaplitt M. Future and current surgical therapies in Parkinson's disease. Curr Opin Neurol 2003; 16: 487-493.
10. Bergman H., Deuschl G. Pathophysiology of Parkinson's disease: from clinical neurology to basic neuroscience and back. Mov Disord 2002; 17 (Suppl 3): S28-S40.

11. Zabek M., Slawek J., Harat M., et al. Stymulacja mózgu i rdzenia kręgowego w leczeniu zaburzeń ruchowych oraz zespołów bólowych - podstawy teoretyczne i zalecenia praktyczne. Neurol Neurochir Pol 2006; 40: 1-9.

12. Friedman A., Harat M., Opala G., et al. Konsensus w zakresie wskazań do leczenia operacyjnego choroby Parkinsona. Neurol Neurochir Pol 2003; 37 (Suppl 5): 11-17.

13. Defer G.L., Widner H., Marié R.M., et al. Core assessment program for surgical interventional therapies in Parkinson's disease (CAPSIT-PD). Mov Disord 1999; 14: 572-584.

14. Pillon B. Neuropsychological assessment for management of patients with deep brain stimulation. Mov Disord 2002; 17 (Suppl 3): S116-S122.

15. Benabid A.L., Koudsie A., Benazzouz A., et al. Imaging of subthalamic nucleus and ventralis intermedius of the thalamus. Mov Disord 2002; 17 (Suppl 3): S123-S129.

16. Benazzouz A., Breit S., Koudsie A., et al. Intraoperative microrecordings of the subthalamic nucleus in Parkinson's disease. Mov Disord 2002; 17 (Suppl 3): S145-S149.

17. Pollak P., Krack P., Fraix V., et al. Intraoperative micro- and macrostimulation of the subthalamic nucleus in Parkinson's disease. Mov Disord 2002; 17 (Suppl 3): S155-S161.

18. Zonenshayn M., Rezai A., Mogilner A., et al. Comparison of anatomic and neurophysiological methods for subthalamic nucleus targeting. Neurosurgery 2000; 47: 282-294.

19. Krack P., Fraix V., Mendes A., et al. Postoperative management of subthalamic nucleus stimulation for Parkinson's disease. Mov Disord 2002; 17 (Suppl 3): S188-S197.

20. Kumar R. Methods for programming and patient management with deep brain stimulation of the globus pallidus for the treatment of advanced Parkinson's disease and dystonia. Mov Disord 2002; 17 (Suppl 3): S198-S207.

21. Ząbek M., Sobstyl M., Koziara H. Obustronna głęboka stymulacja jądra niskowzgórzowego w operacyjnym leczeniu choroby Parkinsona. Neurol Neurochir Pol 2003; 37: 447-457.

22. Cooper I.S. Chemopallidectomy: an investigative technique in geriatric parkinsonians. Science 1955; 121: 217-218.

23. Cooper I.S., Bergmann L.L., Caracalos A. Anatomic verification of the lesion which abolishes parkinsonian tremor and rigidity. Neurology 1963; 13: 779-787.

24. Jankovic J., Cardoso F., Grossman R.G., et al. Outcome after stereotactic thalamotomy for parkinsonian, essential, and other types of tremor. Neurosurgery 1995; 37: 680-686.

25. Limousin P., Pollak P., Benazzouz A. Effect of parkinsonian signs and symptoms of bilateral subthalamic nucleus stimulation. Lancet 1995; 345: 91-95.

26. Krack P., Pollak P., Limousin P. Subthalamic nucleus or internal pallidal stimulation in young onset Parkinson's disease. Brain 1998; 121: 451-457.

27. Umemura A., Jaggi J.L., Hurtig H.I., et al. Deep brain stimulation for movement disorders: morbidity and mortality in 109 patients. J Neurosurg 2003; 98: 779-784.

28. Hariz M. Complications of deep brain stimulation surgery. Mov Disord 2002; 17 (Suppl 3): S162-S166. 
29. Kleiner-Fisman G., Fisman D., Sime E., et al. Long term follow up of bilateral deep brain stimulation of the subthalamic nucleus in patients with advanced Parkinson disease. $J$ Neurosurg 2003; 99: 489-495.

30. Mandat T.S., Hurwitz T., Honey C.R. Hypomania as an adverse effect of subthalamic nucleus stimulation: report of two cases. Acta Neurochir (Wien) 2006; 148: 895-897.

31. Ząbek M., Sobstyl M., Koziara H., et al. Bilateral subthalamic nucleus stimulation in the treatment of advanced Parkinson's disease. Five years' personal experience. Neurol $i$ Neurochir Pol 2010; 44: 3-12.

32. Zabek M., Sobstyl S. Głęboka stymulacja mózgu w leczeniu choroby Parkinsona. Neurol Neurochir Pol 2006; 40: 203-211.

33. Sobstyl M., Dzierzęcki S., Ząbek M., et al. Ocena klinicznej skuteczności głębokiej stymulacji mózgu z zastosowaniem śródoperacyjnego mapowania przestrzennego jąder niskowzgórzowych na podstawie mikrorekordingu. Opis dwóch przypadków. Neurol Neurochir Pol 2007; 41: 76-81.

34. Tykocki T., Mandat T., Nauman P. Wpływ głębokiej stymulacji mózgowej jądra niskowzgórzowego na objawy autonomiczne obserwowane w chorobie Parkinsona. Neurol Neurochir Pol 2010 44: $277-284$ 